IN THE RED CROSS WORLD

\title{
SETTING UP OF AN OPERATIONAL GROUP
}

In the hope of a cease-fire in Indo-China, the International Committee of the Red Cross and the League of Red Cross Societies have set up an operational group entrusted with pooling all Red Cross resources and harmonizing the plans of action in order to assist the conflict victims with the maximum effectiveness. This integration at the operational level in no way changes the respective responsibilities of the two institutions.

Within the framework of this agreement, the ICRC and the League have asked Mr. Olof Stroh, Secretary General of the Swedish Red Cross, to direct the overall operations of the Red Cross in Indo-China. He has the support of a group of experts made available by the ICRC, the League and some National Societies.

A preliminary plan has been worked out in Geneva in anticipation of a cease-fire, which takes into account the programmes already under way and the wishes expressed by various authorities and Red Cross organizations. The plan covers the aspects of present and foreseeable activities in the fields of protection and relief which the Red Cross might be called on to develop. It deals, in particular, with questions of personnel required, the purchase of relief supplies in South-East Asia, transport and storage, communications and information media, as well as contact and coordination with international and national organizations, which are also preparing to go into action once the cease-fire has been announced.

The expenses in the first three months have been estimated at about Sw. Fr. 50 million. To meet the needs already outlined, it is planned to send some sixty delegates into the field. They will make up several teams which will work in close co-operation with the various Red Cross organizations directly interested. The ICRC and League delegations at present in Indo-China will be united and strengthened. 


\section{IN THE RED CROSS WORLD}

An appeal has just been made to all National Red Cross, Red Crescent and Red Lion and Sun Societies to obtain the qualified personnel and financial resources needed.

\section{CONFERENCE OF BALKAN NATIONAL SOCIETIES}

A Conference of Balkan Red Cross and Red Crescent Societies was held at Opatija, Yugoslavia, from 13 to 18 November 1972. Delegates of the Yugoslav, Bulgarian, Romanian and Hellenic Red Cross Societies and of the Turkish Red Crescent participated. The League was represented by Mr. H. Beer, Secretary General, who was accompanied by Mr. V. Semoukha, Mr. Z. Hantchef, Mr. J.-P. Robert-Tissot and other members of the League Secretariat. Lady Limerick, Chairman of the Standing Commission of the International Red Cross, attended the gathering, as did the ICRC, represented by Mr. H. Huber, Vice-President, and Mr. P. Gaillard, Assistant Director, and delegates of the Austrian and Italian Red Cross Societies.

The general purpose of the meeting was to study the humanitarian activities of the Red Cross as a factor contributing to cooperation between National Societies and to friendship between peoples. The agenda included a number of items on which papers were submitted by some of the Societies: Youth Today-The Future belongs to the Young (Bulgaria), The Red Cross in the Field of Health-Health Education of the Public-The Role of the Nurse (Hellenic Red Cross), Red Cross-Factor of Peace (Romanian Red Cross), The Vital Importance of First Aid (Turkish Red Crescent), and Development of International Humanitarian Law (Yugoslav Red Cross). When the latter subject came up for discussion, Mr. Gaillard spoke about the ICRC's activities and the effort which was being made to disseminate the Geneva Conventions. Several Balkan Societies were actively pursuing that effort in their respective countries. With regard to the Red Cross and peace, he reminded the meeting of the educational action launched by the 